\title{
Mole per Day
}

National Cancer Institute

\section{Source}

National Cancer Institute. Mole per Day. NCI Thesaurus. Code C85737.

Moles per day. 